\title{
RESPON PERTUMBUHAN DAN HASIL TIGA VARIETAS SORGUM DI LAHAN PESISIR DENGAN APLIKASI BAHAN ORGANIK DAN FUNGI MIKORIZA ARBUSKULAR
}

\author{
John Marles ${ }^{1}$, E. Apriyanto ${ }^{2}$, P. Harsono ${ }^{3}$ \\ ${ }^{1}$ Dinas Pertanian Kabupaten Seluma, \\ ${ }^{2}$ Jurusan Kehutanan Fakultas Pertanian Universitas Bengkulu, \\ ${ }^{3}$ Jurusan Agroteknologi Fakultas Pertanian Universitas Bengkulu, \\ Email : marles.johnsp@gmail.com
}

\begin{abstract}
ABSTRAK
Penelitian ini bertujuan untuk mengetahui varietas sorgum, jenis aplikasi input FMA atau bahan organik yang sesuai untuk pertumbuhan sorgum di lahan suboptimal pesisir serta menentukan pengaruh interaksi yang terbaik. Penelitian ini dilakukan dengan teknik budidaya sorgum input rendah menggunakan rancangan acak kelompok lengkap dengan dua faktorial sebanyak tiga kali ulangan. Faktor pertama adalah 3 varietas sorgum; Kefa Coklat (V1), Numbu (V2) dan Samurai (V3). Faktor kedua berupa aplikasi fungi mikoriza arbuskular (FMA) dosis $5 \mathrm{~g} / \operatorname{tanaman}$ (P1), kompos sawit dosis 5 ton/ha (P2), bokashi dosis 5 ton/ha (P3). Hasil penelitian menunjukkan bahwa varietas sorgum yang lebih berpotensi untuk dikembangkan di lahan pesisir sebagai hijauan pakan ternak adalah varietas samurai, sedangkan untuk hasil produksi adalah varietas numbu. Bahan pembenah tanah yang tepat untuk pertumbuhan dan hasil di lahan pesisir adalah aplikasi pupuk kandang dengan dosis 5 ton/ha dibandingkan dengan aplikasi pupuk TKKS 5 ton/ ha dan FMA $5 \mathrm{gr} /$ tanaman. Kombinasi Varietas sorgum kefa coklat dengan pupuk kandang sesuai untuk dikembangkan dilahan pesisir sebagai hijauan pakan ternak, sedangkan untuk hasil produksi biji adalah varietas numbu dikombinasikan dengan pupuk kandang.
\end{abstract}

Kata Kunci : Lahan Pesisir, Varietas Sorgum, Pupuk Kandang, Mikoriza

\section{PENDAHULUAN}

Lahan pesisir pantai merupakan lahan marjinal (Widya et al, 2009) yang memiliki keterbatasan pengembangan pertaniaan seperti struktur tanah lepaslepas, kesuburan rendah, bahan organik yang sangat rendah, angin kencang bergaram, evaporasi yang tinggi, temperatur yang tinggi (Kertonegoro, 2001) dan infiltarasi tinggi (Budiyanto, 2001). Prospek peningkatan prokduktifitas lahan marginal sebagai salah satu lahan budidaya pertanian sangat besar, mengingat laju konversi lahan pertanian yakni sekitar 132.000 ha/tahun (Agus dan
Irawan, 2006). Dengan demikian pemanfaatan lahan marginal sangat perlu dilakukan untuk menutupi konversi lahan pertanian yang terjadi setiap tahunnya.

Kota Bengkulu Secara geografis terletak di pantai bagian barat sumatera yang mempunyai potensi sumberdaya pesisir dan lautan yang besar dan beragam. Hal ini disebabkan karena dua pertiga wilayah Kota Bengkulu merupakan kawasan pesisir.

Perbaikan Sifat-sifat tanah seperti sifat fisik, kimia dan biologi tanah sangat diperlukan pada tanah marginal karena akan mempengaruhi tingkat ketersediaan 
unsur hara tanah. Bahan organik merupakan salah satu pembenah tanah yang telah dirasakan manfaatnya dalam perbaikan sifat-sifat tanah baik sifat fisik, kimia dan biologi tanah. Hasil penelitian Rajiman, et al. (2008) bahwa dengan bahan organik dan limbah karbit 20 ton per hektar di tanah pasir pantai nyata meningkatkan jumlah fraksi lempung, debu, pori mikro, kadar lengas, menurunkan berat volume, berat jenis dan meningkatkan berat segar, berat kering, berat kering oven dan diameter umbi bawang merah dibanding kontrol.

Bahan organik sisa pertanian dan peternakan sangat melimpah disekitar kita, yang bisa dimanfaatkan sebagai bahan pupuk organik. Jenis pupuk organik diantaranya pupuk Kandang dan pupuk tandan kosong kelapa sawit (TKKS). Pupuk Kandang adalah pupuk yang dihasilkan dari kotoran sapi melalui fermentasi dengan pemberian Effektive Mikroorganisme-4 (EM-4) yang merupakan salah satu aktivator untuk mempercepat proses pembuatan pupuk (Indriani, 2001). Pemanfaatan pupuk tandan kosong kelapa Sawit (TKKS) telah banyak dicobakan pada berbagai komoditi pangan maupun hortikultura sebagai pupuk organik, Keunggulan pupuk TKKS adalah memperbaiki sifat fisik, kimia dan biologi (Nasution, et al, 2017)

Faktor lain yang terlibat dalam pembentukan struktur adalah organisme tanah (Hakim et al, 1986). Agen organik sangat penting dalam menstabilkan agregat mikro melalui kekuatan perekat dan pengikatan oleh asam-asam serta hifa sehingga akan terbentuk agregat makro yang mantap. Mikoriza merupakan salah satu agen hayati yang mampu memperbaiki struktur tanah. Inokulasi mikoriza pada tanaman bawang di tanah bertekstur lempung liat berpasir secara nyata menyebabkan agregat tanah menjadi lebih baik, lebih berpori dan memiliki permeabilitas yang tinggi, namun tetap memiliki kemampuan memegang air yang cukup untuk menjaga kelembaban tanah (Subiksa, 2002).

Sorgum (Sorghum bicolor L) merupakan tanaman serealia yang mempunyai daerah adaptasi sangat luas dan merupakan sumber karbohidrat penting yang berpotensi besar dikembangkan di Indonesia (Sirappa, 2010). Sorgum adalah salah satu bahan pangan yang potensial untuk diversifikasi pangan, substitusi terigu dan beras karena masih satu famili dengan gandum dan padi, karakteristik tepungnya relatif lebih baik dibanding tepung umbi-umbian, kandungan karbohidratnya sorgum cukup tinggi, sekitar $73 \mathrm{~g} / 100 \mathrm{~g}$ bahan melebihi kadar kabohidrat beras (Direktorat Jenderal Tanaman Pangan dan Hortikultura, 1996), Selain itu hijauan sorgum juga dimanfaat untuk pakan ternak.

Sorgum sangat cocok dibudidayakan di lahan kering karena kebutuhan terhadap air lebih sedikit dibandingkan dengan tanaman pangan lainnya seperti jagung, gandum, dan padi. Menurut Tacoh et al.,(2017). Sorgum memiliki beberapa keunggulan seperti dapat tumbuh di lahan kering, resiko kegagalan relatif kecil, kandungan nutrisi cukup tinggi, relatif lebih tahan hama penyakit dibandingkan tanaman pangan lainnya serta pembiayaan usahatani relatif murah.

Selain keunggulan dan kelebihan tanaman sorgum dibandingkan dengan tanaman pangan lainnya setelah mengenal tanaman sorgum melalui penelitian tentang budidaya dan pelatihan produk olahan dari sorgum dikelurahan setempat apresiasi masyarakat kelurahan Kandang Mas terhadap sorgum sangat tinggi. Hal ini mendasari tanaman sorgum menjadi komoditi yang berpotensi untuk dikembangkan di lahan pesisir daerah kelurahan Kandang Mas. 


\section{METODE PENELITIAN}

\section{Waktu dan Tempat}

Penelitian dilaksanakan pada Mei-Juli 2017 di Kelurahan Kandang Mas Kecamatan Kampung Melayu, dengan ketinggian tempat 5 meter dari permukaan laut (dpl)

\section{Rancangan Percobaan}

Penelitian ini menggunakan

Rancangan Acak Kelompok Lengkap (RAKL) 2 faktor dan 3 ulangan.Faktor pertama adalah 3 varietas sorgum; Kawali (V1), Numbu (V2) dan Samurai (V3). Faktor kedua berupa aplikasi fungi mikoriza arbuskular (FMA) dosis 5 g/tanaman (P1), kompos sawit dosis 2 ton/ha (P2), bokashi dosis 2 ton/ha (P3). Variabel yang diamati meliputi tinggi tanaman (TT), jumlah daun (JD), diameter batang (DB), berat segar tanaman (BST), berat kering tanaman (BKT), jumlah ruas (JR), berat malai (BM), panjang malai (PM), dan kadar gula (KG). Data hasil pengamatan dianalisis secara statistik dengan menggunakan uji $\mathrm{F} 5 \%$ dan $1 \%$. Variabel yang berbeda nyata diuji lanjut dengan DMRT taraf 5\%.

\section{HASIL DAN PEMBAHASAN}

\section{Gambaran Umum Penelitian}

Pelaksanaan penanaman dilakukan pada tanggal 13 April 2017. Pada fase pertumbuhan vegetatif tanaman sorgum tumbuh dengan baik, setelah masuk ke fase generatif terjadi serangan jamur yang ditandai bercak-bercak pada daun dan menyerang malai sehingga menghambat pengisian biji sorgum yang ditandai dengan kosong biji dan selanjutnya malai mengering.

Upaya pengendalian serangan jamur menggunakan fungisida, namun pada tanaman yang sudah terserang cukup parah sudah sulit untuk dikendalikan, sehingga berpengaruh terhadap produksi.

\section{Analisis Tanah dan Infeksi Fungi Mikoriza Arbuskular (FMA)}

\section{Analisa Tanah}

Indikator kualitas tanah yang paling utama adalah kadar bahan organik, $\mathrm{N}, \mathrm{P}$ dan $\mathrm{K}$ tersedia. Indikator tersebut merupakan faktor utama yang erat hubungannya dengan pertumbuhan tanaman, produksi tanaman mempengaruhi fungsi dan keragaman mikroorganisme tanah.

Peningkatan unsur $\mathrm{N}, \mathrm{P}$ dan $\mathrm{K}$ tanah pada lahan penelitian terlihat pada tabel 1 Hal ini di asumsikan dengan penambahan bahan organik dan FMA dapat meningkatkan ketersediaan unsur $\mathrm{N}$, $\mathrm{P}$ dan $\mathrm{K}$ pada tanah. pupuk kandang dapat menyediakan unsur hara makro $(\mathrm{N}, \mathrm{P}, \mathrm{K})$ dan mikro ( $\mathrm{Ca}, \mathrm{Mg}, \mathrm{S}, \mathrm{Na}, \mathrm{Fe}, \mathrm{Cu}, \mathrm{Mo}$ ) Rosmarkam dan Yuwono (2002), enzim phosphatase yang dihasilkan FMA dapat melepaskan $\mathrm{P}$ dari ikatan-ikatan spesifik (molekul Mikro), sehingga unsur P yang tersedia mampu diserap oleh tanaman.

\section{Infeksi Fungi Mikoriza Arbuskular (FMA)}

Hasil analisis akar sorgum pada perlakuan aplikasi FMA 5 gr/ Tanaman didapat hasil infeksi akar sorgum pada perlakuan V1P1 sebesar $70 \%$, V2P1 sebesar 10\% dan V3P1 sebesar $100 \%$, hal ini menunjukan bahwa FMA menginfeksi akar sorgum.

\section{Pertumbuhan Tanaman Sorgum}

Perlakuan tunggal varietas Kefa coklat menghasilkan pertumbuhan sorgum lebih baik dari pada varietas Numbu dan samurai (Tabel 3). Hal ini karena kemampuan tanaman beradaptasi dengan lingkungan menjadi salah satu faktor pertumbuhana tanaman. Selain itu menurut Effendi (2012) pertumbuhan yang berbeda antar varietas sorgum diduga disebabkan oleh adanya perbedaan 
kecepatan pembelahan, perbanyakan dan pembesaran sel.

Mangoendidjojo (2003) dalam Zulkarnaen et al (2015) menyatakan bahwa varietas merupakan sekumpulan individu tanaman yang dapat dibedakan oleh setiap sifat (morfologi, fisiologi, sitology, kimia dll) yang nyata untuk usaha pertanian dan bila diproduksi kembali akan menunjukkan sifat-sifat yang dapat dibedakan dari yang lain. Hasil penelitian ini menunjukkan bahwa varietas Kefa coklat memiliki kemampuan adaptasi terhadap lingkungan penelitian yang merupakan lahan marginal dibanding dengan varietas Numbu dan Samurai.

Secara umum perlakuan varietas berpengaruh nyata terhadap pertumbuhan sorgum dan berpengaruh tidak nyata terhadap hasil sorgum. Dengan faktor genetik yang dimiliki Varietas numbu, sangat mendukung untuk dapat beradaptasi lebih baik di lahan pesisir dibandingkan varietas kefa coklat dan samurai sehingga pertumbuhannya lebih tinggi. Hal tersebut dapat bahwa varietas numbu memiliki bobot segar pertanaman lebih tinggi dari varietas kefa coklat dan samurai. Pupuk kandang menghasilkan

Tabel 1. Hasil analisa sifat kimia tanah sebelum dan sesudah penelitian

\begin{tabular}{lcccc}
\hline Parameter Tanah & N-total $(\%)$ & $\begin{array}{c}\text { P-bray } \\
(\mathbf{p p m})\end{array}$ & $\begin{array}{c}\mathbf{K} \\
(\mathbf{m g} / \mathbf{1 0 0 g r})\end{array}$ & $\begin{array}{c}\text { C-organik } \\
(\mathbf{\%})\end{array}$ \\
\hline Tanah awal & 0,22 & 0,28 & 4,42 & 2,44 \\
& $(0,21-$ & $(<10)$ & $(<10)$ & $(2,01-3,00)$ \\
& $0,50)^{*}$ & Sangat & Sedang \\
& Sedang & Rendah & Rendah & \\
\hline Aplikasi pupuk & 0,39 & 2,82 & 8,86 & 3,50 \\
Kandang & $(0,21-0,50)$ & $(<10)$ & $(<10)$ & $(2,01-3,00)$ \\
& Sedang & Sangat & Sangat & Sedang \\
& & Rendah & Rendah & \\
\hline Aplikasi FMA & 0,34 & 5,61 & 10,45 & 3,21 \\
& $(0,21-0,50)$ & $(<10)$ & $(10-15)$ & $(2,01-3,00)$ \\
& Sedang & Sangat & Rendah & Sedang \\
& & Rendah & & \\
\hline TKKS** & $(3,62 \%)$ & $(0,94 \%)$ & $0,62 \%)$. & - \\
& $>0,75$ & $(<10)$ & $(<10)$ & \\
& $($ sangat & Sangat & Sangat & \\
& Tinggi) & Rendah & Rendah & \\
\hline
\end{tabular}

Keterangan : hasil analisa laboraterium Ilmu Tanah Universitas Bengkulu 2017

* Kriteria Penilaian Sifat Kimia Tanah (BPT, 2005)

** Hasil analisis hara TKKS penelitian Hayat E. S., dan S Andayani, 2014

Tabel 2 Hasil analisa Fungi Mikoriza Arbuskular (FMA) pada akar sesudah penelitian.

\begin{tabular}{cc} 
Perlakuan & Infeksi mikoriza (\%) \\
\hline V1P1 & 70 \\
V2P1 & 10 \\
V3P1 & 100 \\
\hline
\end{tabular}

Ket: 1. V1=varietas Kefa coklat, V2=varietas numbu, V3=varietas samurai, P1=FMA (5g/tan), $\mathrm{P} 2=$ pupuk TKKS (2 ton/ha), P3=kandang (2 ton/ha) 
tinggi tanaman $(76 \mathrm{~cm})$ dan bobot segar tanaman $(332,98 \mathrm{~cm})$ lebih lebih tinggi dibandingkan pupuk TKKS dan FMA (tabel 4). Hal ini karena aplikasi pupuk kandang mampu meningkatkan serapan hara bagi tanaman. Menurut Kaya (2013) pupuk kandang mengandung mikroorganisme tanah efektif sebagai depupuker yang dapat mempercepat proses depupukisi bahan organik dalam tanah, sehingga dapat meningkatkan ketersediaan unsur hara $\mathrm{N}, \mathrm{P}$ dan $\mathrm{K}$ bagi tanaman.

Secara umum hasil uji lanjut DMRT taraf $5 \%$ pengaruh aplikasi pupuk kandang 5 ton/ha menghasilkan pertumbuhan dan hasil sorgum lebih tinggi dibandingkan aplikasi dari Pupuk TKKS dan FMA. Dengan semakin tingginya dosis pupuk kandang maka pertumbuhan dan hasil sorgum juga semakin tinggi. Hal tersebut dikarenakan aplikasi pupuk kandang lebih berkontribusi dalam meningkatkan kesuburan tanah dan ketersedian hara sehingga dapat meningkatkan daya serap akar terhadap air dan unsur hara yang ada dalam tanah.
Penelitian Dwinda R, (2017) pada lokasi dan waktu penelitan yang sama menunjukan pada tanaman kontrol sorgum tanpa Pemberian tanpa pupuk kandang dan mikoriza menghasilkan bobot basah tanaman yaitu 392,2 gram, lebih tinggi dibandingkan dg bobot segar tanaman yang dihasilkan. Artinya bila dilihat dari hal tersebut aplikasi bahan organik disini belum dianggap perlu, namun diasumsikan lahan penelitian yang digunakan untuk tiap petak percobaan tidak homogen.

Hasil uji DMRT pengaruh interaksi varietas sorgum dan jenis pupuk terhadap pertumbuhan sorgum disajikan Tabel 5. Interaksi varietas Kefa coklat dengan pupuk kandang menghasilkan tinggi tanaman lebih tinggi dan diameter batang lebih besar, hal ini menunjukkan bahwa varietas Kefa coklat memberikan respon terbaik terhadap pemberian pupuk kandang dibanding dengan kombinasi lainnya, namun Pada variabel yang sama interaksi varietas samurai dan pupuk kandang menghasilkan tinggi tanaman terendah dan diameter batang terkecil.

Tabel 3. Pengaruh tunggal perlakuan Varietas (V) terhadap pertumbuhan sorgum

\begin{tabular}{ccccccc}
\hline Perlakuan & TT $(\mathrm{cm})$ & JD (helai) & DB $(\mathrm{cm})$ & BST (gr) & BKT (gr) & $\begin{array}{c}\text { JR } \\
(\mathrm{buah})\end{array}$ \\
\hline Kefa coklat & $95,25 \mathrm{a}$ & $10,67 \mathrm{a}$ & $1,13 \mathrm{a}$ & $319,17 \mathrm{a}$ & $50,85 \mathrm{a}$ & $9,67 \mathrm{a}$ \\
Numbu & $72,53 \mathrm{~b}$ & $9,77 \mathrm{~b}$ & $1,07 \mathrm{a}$ & $256,79 \mathrm{c}$ & $29,17 \mathrm{~b}$ & $8,77 \mathrm{~b}$ \\
Samurai & $48,92 \mathrm{c}$ & $9,60 \mathrm{~b}$ & $0,77 \mathrm{~b}$ & $284,19 \mathrm{~b}$ & $13,72 \mathrm{c}$ & $8,60 \mathrm{~b}$ \\
\hline
\end{tabular}

Ket : TT : Tinggi Tanaman, JD : Jumlah daun, DB: Diameter Batang, BST : Berat Basah Tanaman, BKT : Berat Kering Tanaman, JR : Jumlah Ruas.

Angka yang diikuti huruf yang sama pada kolom yang sama menunjukan tidak berbeda nyata pada uji Duncan taraf 5\%

Tabel 4. Pengaruh tunggal perlakuan pupuk $(\mathrm{P})$ terhadap pertumbuhan sorgum

\begin{tabular}{cll}
\hline Perlakuan & TT $(\mathrm{cm})$ & BST $(\mathrm{gr})$ \\
\hline FMA & $69,61 \mathrm{~b}$ & $256,19 \mathrm{~b}$ \\
Pupuk TKKS & $71,08 \mathrm{~b}$ & $270,98 \mathrm{~b}$ \\
Pupuk Kandang & $76,00 \mathrm{a}$ & $332,98 \mathrm{a}$ \\
\hline
\end{tabular}

Ket : TT : Tinggi Tanaman, BST : Berat Basah Tanaman

Angka yang diikuti huruf yang sama pada kolom yang sama menunjukan tidak berbeda nyata pada uji Duncan taraf 5\% 
Kombinasi varietas Samurai dengan pupuk kandang menghasilkan bobot segar tanaman tertinggi dan pada peubah yang sama interaksi varietas samurai dan FMA menghasilkan bobot segar tanaman terendah. Bobot kering tertinggi terdapat pada interaksi varietas Kefa coklat dan aplikasi FMA, dan pada variabel yang sama interaksi varietas samurai dan FMA menghasilkan berat kering tanaman terendah. Pada peubah hasil Interaksi varietas Numbu dan pupuk kandang menghasilkan panjang malai terpanjang dan kadar gula tertinggi, dan pada variabel yang sama interaksi varietas samurai dan pupuk TKKS menghasilkan panjang malai terendah, dan pada interaksi varietas numbu dengan pupuk TKKS dan atau FMA menghasilkan kadar gula terendah. Nasir (2002) menyatakan hasil maksimum dapat dicapai bila kultivar unggul menerima respon terhadap kombinasi optimum dari air, pupuk dan praktek budidaya lainnya. Selain itu aplikasi pupuk kandang mampu meningkatkan ketersediaan unsur hara dan perbaikan sifat fisik dan kimia tanah sehingga pertumbuhan sorgum meningkat. Menurut Syam (2003) pupuk kandang yang ditambahkan dalam tanah menyumbangkan unsur-unsur $\mathrm{N}, \mathrm{P}$ dan $\mathrm{K}$, sehingga dapat meningkatkan ketersediaan unsur- unsur tersebut dalam tanah.

Kombinasi varietas Samurai dengan pupuk kandang menghasilkan bobot segar tanaman tertinggi (Tabel 5). Sumardi et al. (2007); Soplanit (2012) menyatakan pupuk kandang mengandung mikroorganisme bermanfaat yang merupakan bagian integral dari tanah, mampu menyediakan hara tanaman melalui proses daur ulang serta membentuk struktur tanah yang sesuai untuk pertumbuhan tanaman. Kombinasi varietas Samurai dengan pupuk kandang menghasilkan bobot segar tanaman terendah diduga karena secara genetis varietas samurai memiliki karakteristik lebih banyak mengandung kadar air, sehingga pada variabel bobot kering tanaman varietas samurai menghasilkan bobot kering terendah. Bobot segar tanaman dipengaruhi oleh kadar air dan kandungan unsur hara yang ada pada sel jaringan tanaman. Faktor yang mempengaruhi produktivitas sorgum tergolong tinggi karena dan memiliki lapisan lilin pada permukaan daun yang dapat mengurangi laju evapotranspirasi, dan sistem perakarannya ekstensif, hal menjadikan sorgum sangat efisien dalam pemanfaatan air sehingga produktivitas biomasnya lebih tinggi dibandingkan

Tabel 5. Pengaruh interaksi varietas dan jenis pupuk terhadap pertumbuhan sorgum

\begin{tabular}{ccccc}
\hline Perlakuan & $\begin{array}{c}\text { Tinggi } \\
\text { Tanaman }(\mathrm{cm})\end{array}$ & $\begin{array}{c}\text { Diameter } \\
\text { Batang }(\mathrm{cm})\end{array}$ & $\begin{array}{c}\text { Berat Basah } \\
\text { Tanaman }(\mathrm{gr})\end{array}$ & $\begin{array}{c}\text { Berat Kering } \\
\text { Tanaman }(\mathrm{gr})\end{array}$ \\
\hline V1P1 & $82,17 \mathrm{~b}$ & $0,91 \mathrm{bc}$ & $341,75 \mathrm{~b}$ & $61,20 \mathrm{a}$ \\
V1P2 & $85,00 \mathrm{~b}$ & $0,94 \mathrm{bc}$ & $328,00 \mathrm{bc}$ & $52,55 \mathrm{ab}$ \\
V1P3 & $118,58 \mathrm{a}$ & $1,53 \mathrm{a}$ & $287,75 \mathrm{~d}$ & $38,80 \mathrm{c}$ \\
V2P1 & $71,58 \mathrm{~d}$ & $1,13 \mathrm{~b}$ & $229,00 \mathrm{e}$ & $17,50 \mathrm{de}$ \\
V2P2 & $78,17 \mathrm{c}$ & $1,13 \mathrm{~b}$ & $240,19 \mathrm{e}$ & $23,30 \mathrm{~d}$ \\
V2P3 & $67,83 \mathrm{e}$ & $0,94 \mathrm{bc}$ & $301,19 \mathrm{~cd}$ & $46,70 \mathrm{bc}$ \\
V3P1 & $41,58 \mathrm{~h}$ & $0,53 \mathrm{~d}$ & $197,81 \mathrm{f}$ & $9,30 \mathrm{e}$ \\
V3P2 & $50,08 \mathrm{~g}$ & $0,72 \mathrm{~cd}$ & $244,75 \mathrm{e}$ & $10,85 \mathrm{e}$ \\
V3P3 & $55,08 \mathrm{f}$ & $1,06 \mathrm{~b}$ & $410,00 \mathrm{a}$ & $21,00 \mathrm{~d}$ \\
\hline Ket : 1. V1=varietas Kefa coklat, V2=varietas numbu, V3=varietas samurai, P1=FMA $(5 \mathrm{~g} / \tan )$, \\
P2=pupuk TKKS $(2$ ton/ha), P3=kandang $(2$ ton/ha) \\
2. Angka yang diikuti huruf yang sama menunjukan tidak berbeda nyata pada uji \\
Duncan taraf 5\%
\end{tabular}


dengan jagung atau tebu yang sama-sama tanaman (Hoeman, S., 2007).

Bobot segar tanaman sorgum berupa batang dan daun disebut juga hijauan sorgum dapat dimanfaatkan sebagai pakan ternak ruminansia. Hasil hijauan untuk pakan ternak merupakan hasil panen dari batang dan daun tanaman (Koten, et.al.,2014). Batang dan daun sorgum memiliki rasa manis dan renyah serta dapat dimanfaatkan untuk pakan ternak, terutama sapi. Di Australia, batang dan daun sorgum telah dikembangkan menjadi forage sorgum dan sweet sorgum untuk pakan (Irawan dan Sutrisna 2011). sebelum memasuki fase generatif yaitu pada umur 60 hst,, tanaman akan lebih banyak memproduksi daripada yang digunakan. Kelebihan hasil asimilasi ini akan disimpan pada bagian vegetatif sebagai senyawa cadangan yang ditranslokasikan pada area akar, batang dan daun sebagai cadangan makanan. Cadangan makanan dalam bentuk daun dan batang inilah kemudian di panen sebagai hasil hijauan yang digunakan untuk pakan ternak. Menurut Sirappa (2003), sorgum merupakan tanaman penghasil bahan pakan hijauan sekitar 3 ton/ha dan pada kondisi optimum dapat mencapai 30-45 ton/ha/th dalam bentuk bahan segar. Dengan nilai bobot segar tanaman tertinggi pada varietas samurai dengan kombinasi pupuk kandang sebesar $410 \mathrm{gr}$ artinya bahan hijauan yang mampu di hasilkan dari varietas samurai adalah sebanyak 27 ton/ ha. Hal ini menunjukkan bahwa hasil bahan hijauan sorgum dari varietas samurai lebih banyak dibandingakn varietas numbu dan kefa coklat, sehingga varietas samurai cendrung sangat potensial untuk dikembangkan sebagai pakan ternak.

Bobot kering tertinggi terdapat pada kombinasi varietas Kefa coklat dan aplikasi FMA. Sedangkan pada jumlah ruas interaksi varietas Kefa coklat dan pupuk TKKS merupakan yang terbaik, namun berbeda tidak nyata dengan varietas kefa coklat yang diaplikan FMA maupun pupuk kandang. Hal ini diduga karena infeksi FMA lebih banyak dibandingkan aplikasi pupuk kandang dan pupuk TKKS, dengan tidak diberikan asupan hara tambahan menyebabkan pengaruh FMA lebih maksimal, hal ini terlihat dari uji laboraterium pada kombinasi varietas kefa dengan FMA menunjukan infeksi $100 \%$ dan dapat dilihat pada foto infeksi FMA. Menurut Cameron (2010) bahwa tanaman yang diberi inokulan FMA mempunyai produktivitas lebih tinggi dibandingkan tanaman yang tumbuh tanpa diberi inokulan FMA. Penggunaan cendawan mikoriza sebagai alat biologis dalam bidang pertanian dapat memperbaiki pertumbuhan, produktivitas dan kualitas tanaman tanpa menurunkan kualitas ekosistem tanah. Selain itu aplikasi cendawan mikoriza dapat membantu rehabilitasi lahan kritis dan meningkatkan produktivitas tanaman pertanian pada lahan-lahan marginal (Syah, 2007). Hal ini diperkuat dengan hasil penelitian Bertham (2007) bahwa inokulasi ganda Rhizobium dan FMA dilaporkan dapat mempengaruhi bobot kering tanaman, serapan hara $\mathrm{P}$ oleh tanaman jumlah polong dan jumlah bintil akar.

\section{Produktivitas Tanaman Sorgum}

Varietas Numbu menghasilkan panjang malai lebih tinggi dari varietas Kefa coklat dan Samurai (Tabel 7). Hal ini mengidikasikan bahwa varietas Numbu memiliki tingkat adaptasi lebih baik dari varietas Kefa coklat dan Samurai. Munthe, (2013) menunjukkan bahwa Varietas Numbu memberikan hasil yang lebih baik pada bobot kering tajuk, bobot biomassa, volume akar, produksi per sampel, bobot 1000 biji dibandingkan dengan dua varietas lainnya. Varietas yang berbeda yang ditanam pada tempat yang sama menunjukkan respon yang 
berbeda pada komponen pertumbuhan dan hasil tanaman (Zulkarnaen et al, 2015). Menurut Poerwanto (2003) produktivitas tanaman sangat tergantung pada kemampuan tanaman berfotosintesis dan mengalokasikan sebagian besar hasil fotosintesis tersebut ke organ.

Secara tunggal aplikasi pupuk kandang menghasilkan panjang malai terpanjang $(23,73 \mathrm{~cm})$ dan kadar gula tertinggi (11,58 Brix) (Tabel 7). Hal ini berkaitan dengan peranan kandang dalam meningkatkan kesuburan tanah. Menurut Wariyanto (2002) pemanfaatan pupuk kandang secara rutin dapat berdampak nyata terhadap peningkatan kesuburan lahan, tanah menjadi gembur, serta sifat fisik, kimia dan biologi tanah menjadi lebih baik. Hasil uji lanjut DMRT pengaruh interaksi antara varietas sorgum dan jenis pupuk terhadap produksi sorgum disajikan pada Tabel 7. Kombinasi Numbu dan pupuk TKKS menghasilkan panjang malai terpanjang $(26,75 \mathrm{~cm})$ dan kadar gula tertinggi (13,50 Brix) (Tabel 7). Perbedaan panjang malai kadar gula dapat disebabkan oleh perbedaan varietas. Pada variabel kadar gula, varietas menentukan umur panen dan secara langsung berperan dalam menentukan kadar kemanisan pada tanaman sorgum. Selain itu, kandungan gula dalam batang sorgum manis juga dipengaruhi oleh jenis sorgum, iklim, umur sorgum, dan cara pemeliharaan, meliputi pemberian pupuk dan pengairan. Menurut Subeni (2000), kadar gula tanaman dipengaruhi oleh kemampuan tanaman untuk beradaptasi terhadap lingkungan tempat tumbuhnya,

Tabel 6. Pengaruh tunggal perlakuan varietas terhadap produksi tanaman sorgum

\begin{tabular}{lcc}
\hline \multicolumn{1}{c}{ Perlakuan varietas } & Panjang Malai $(\mathrm{cm})$ & Bobot 1000 biji \\
\hline Kefa coklat & $20,75 \mathrm{~b}$ & $40,10 \mathrm{~b}$ \\
Numbu & $24,33 \mathrm{a}$ & $50,03 \mathrm{a}$ \\
Samurai & $21,96 \mathrm{~b}$ & $39,87 \mathrm{c}$ \\
\hline \multicolumn{1}{c}{ Perlakuan pupuk } & Panjang Malai & Kadar gula (Brix) \\
\hline FMA & $21,65 \mathrm{~b}$ & $10,25 \mathrm{~b}$ \\
Pupuk TKKS & $21,67 \mathrm{~b}$ & $10,50 \mathrm{~b}$ \\
Pupuk Kandang & $23,73 \mathrm{a}$ & $11,58 \mathrm{a}$ \\
\hline
\end{tabular}

Ket : Angka yang diikuti huruf yang sama pada kolom yang sama menunjukan tidak berbeda nyata pada uji DMRT taraf 5\%

Tabel 7. Pengaruh interaksi varietas dan jenis pupuk terhadap produksi tanaman sorgum

\begin{tabular}{ccc}
\hline Perlakuan & Panjang Malai $(\mathrm{cm})$ & Kadar gula $($ Brix $)$ \\
\hline V1P1 & $21,25 \mathrm{~cd}$ & $11,50 \mathrm{bc}$ \\
V1P2 & $20,25 \mathrm{~d}$ & $10,25 \mathrm{~cd}$ \\
V1P3 & $20,75 \mathrm{~d}$ & $11,50 \mathrm{bc}$ \\
V2P1 & $21,50 \mathrm{~cd}$ & $9,25 \mathrm{~d}$ \\
V2P2 & $24,75 \mathrm{ab}$ & $9,25 \mathrm{~d}$ \\
V2P3 & $26,75 \mathrm{a}$ & $13,50 \mathrm{a}$ \\
V3P1 & $22,19 \mathrm{~cd}$ & $10,00 \mathrm{~d}$ \\
V3P2 & $20,00 \mathrm{~d}$ & $12,00 \mathrm{~b}$ \\
V3P3 & $23,70 \mathrm{bc}$ & $9,75 \mathrm{~d}$ \\
\hline
\end{tabular}

Ket : 1.V1=varietas Kefa coklat, V2=varietas numbu, V3=varietas samurai, P1=FMA (5g/tan), P2=pupuk TKKS (2 ton/ha), P3=kandang (2 ton/ha)

2. Angka yang diikuti huruf yang sama menunjukan tidak berbeda nyata pada uji Duncan taraf $5 \%$. 
sehingga proses fotosintesisnya dapat berjalan baik. Nasir (2002) menyatakan bahwa hasil maksimum dapat dicapai bila kultivar unggul menerima respons terhadap kombinasi optimum dari air, pupuk dan praktek budidaya lainnya. Selain itu proses fotosintesis akan berjalan dengan baik apabila unsur hara tersedia dalam tanah. Aplikasi pupuk kandang diasumsikan mampu meningkatkan ketersedian unsur hara tanah untuk dapat diserap akar, sehingga yang diproses dalam fotosintesis akan meningkat juga. Proses fotosintesis akan menghasilkan senyawa sederhana seperti karbohidrat, lemak, protein (Sulandjari, 2008). Semakin tinggi karbohidrat yang dihasilkan maka semakin tinggi kadar gula yang tersimpan pada batang.

Hasil penelitian menunjukkan bahwa varietas numbuh memiliki respon lebih baik pada pemberian pupuk TKKS 5 ton/ sehingga kadar gula yang dihasilkan lebih tinggi dari varietas lainnya. potensi tumbuh tanaman sorgum dipengaruhi oleh sifat genetis varietas, kondisi atau iklim dan lingkungan tempat tumbuh serta perlakuan budidayanya. Dilihat dari deskripsinya,Varietas numbu memang di kategorikan sorgum manis. Sorgum yang mempunyai kadar gula brix tinggi pada batang digolongkan sebagai sorgum manis (Reddy and Sanjana 2003).

Agustina, (2004) menyatakan bahwa pemberian pupuk kandang sapi dapat meningkatkan unsur N, P dan K tanah. Meningkatnya kadar nitrogen tanah meningkatkan pula kadar nitrogen pada jaringan tanaman. Semakin tinggi kadar nitrogen pada jaringan akan lebih memacu pertumbuhan tanaman, sehingga dapat menyebabkan tanaman menjadi lebih tinggi.

\section{KESIMPULAN}

Berdasarkan hasil penelitian dapat disimpulkan bahwa :
1. Varietas sorgum yang lebih berpotensi untuk dikembangkan dilahan pesisir sebagai hijauan pakan ternak adalah varietas samurai, sedangkan untuk hasil produksi adalah varietas numbu

2. Bahan pembenah tanah yang tepat untuk pertumbuhan dan hasil dikawasan pesisir adalah Aplikasi pupuk kandang dengan dosisi 5 ton/ ha dibandingkan dengan aplikasi pupuk TKKS 5 ton/ ha dan FMA 5 gr/ tanaman

3. 'Kombinasi Varietas sorgum kefa coklat dengan pupuk kandang sesuai untuk dikembangkan dilahan pesisir sebagai hijauan pakan ternak, sedangkan untuk hasil produksi biji adalah varietas numbu dikombinasikan dengan pupuk kandang.

\section{DAFTAR PUSTAKA}

Agus, F. Dan Irawan. 2006. Agricultural land conversion as a threat to food security and environmental quality. Prosiding seminar Multifungsi dan Revitalisasi Pertanian. Kerjasama Badan Litbang Pertania, MAFF, dan ASEAN Secretariat. Hal 101-121

Agustina, L. 2004. Dasar Nutrisi Tanaman. Rineka Cipta. Jakarta

Bertham. 2007. Dampak Inokulasi Ganda Fungi Mikoriza Arbuskular dan Rhizobium Indigenious pada 3 Genotipe Kedelai di Tanah Ultisol. Program Studi IlmuTanah, Fakultas Pertanian Universitas Bengkulu. Jurnal Akta Agrosia Edisi Khusus.(2): $189-198$

Budiyanto. G,2001. Pemanfaatan Canpuran Lempung dan Blontong dalam Memperbaiki Sifat Tanah Pasir Pantai Selatan Yogyakarta. J.agyUMY. IX (1) : 1-12Chandra, Feriana. 2010. Formulasi Snack bar Tinggi Serat Berbasis Tepung Sorgum (Sorghum Bicolor 1), 
Tepung Maizena, dan Tepung Ampas Tahu. Skripsi. Institut Pertanian Bogor. Bogor

Cameron, D.D. 2010. Arbuscular Mycorrhizal Fungi as (Agro) Ecosystem Engineers. Journal of Plant Soil No. 333 Hlm:1-5.

Direktorat Jenderal Tanaman Pangan dan Hortikultura. 1996. Prospek Sorgum Sebagai Bahan Pangan dan Industri Pangan. Risalah Simposium Prospek Tanaman Sorgum untuk Pengembangan Agroindustri, 17-18 Januari 1995. Edisi Khusus Balai Penelitian Tanaman Kacangkacangan dan Umbi-umbian No. 41996: 2-5.

Dwinda R.,2017. Pemanfaatan Canpuran Lempung dan Blontong dalam Memperbaiki Sifat Tanah Pasir Pantai Selatan Yogyakarta. J.agyUMY. IX (1) : 1-12Chandra, Feriana. 2010. Formulasi Snack bar Tinggi Serat Berbasis Tepung Sorgum (Sorghum Bicolor 1), Tepung Maizena, dan Tepung Ampas Tahu. Skripsi. Institut Pertanian Bogor. Bogor

Hoeman, S. 2007. Peluang dan potensi pengembangan sorgum. Makalah pada Workshop - Peluang dan tantangan sorgum sebagai bahan baku bioetanol. Dirjen Perkebunan, Departemen Pertanian. Jakarta. 10 hal

Indriani, Y.H. 2011. Membuat Pupuk Secara Kilat. Penebar Swadaya. Jakarta.

Irawan, B. dan N. Sutrisna. 2011. Prospek pengembangan sorgum di jawa barat mendukung diversifikasi pangan. Forum Agro Ekonomi 29 (2C).

Kaya E. 2013. Pengaruh pupuk jerami dan pupuk NPK terhadap N-tersedia tanah, serapan- $N$, pertumbuhan, dan hasil padi sawah (Oryza sativa L). Agrologia. 2(1):43-50

Kertonegoro, B. D. 2001. Gumuk Pasir Pantai Di D.I Yogyarta : Potensi dan Pemanfaatannya untuk Pertanian Berkelanjuta. Prosiding Seminar Nasional Pemanfaatan Sumberdaya Lokal untuk Pembangunan Pertanian Berkelanjutan. Universitas Wangsa Manggala Yogyakarta

Koten, B. B., R. D. Soetrisno., N. Ngadiyono dan B. Soewignyo. 2014. Perubahan Nilai Nutrien Tanaman Sorgum ( Sorghum bicolor (L) Moench) Varietas lokal Rote sebagai Hijauan Pakan Ruminansia Pada Berbagai Umur Panen dan Dosis Pupuk Urea. Jurnal Sain Peternakan Vol. 3 No. $2: 55-60$.

Leonard Septian Munthe, 2012. Respons Pertumbuhan dan Produksi Tiga Varietas Sorgum (Sorghum bicolor (L.) Moench) Dengan Perbedaan Sistem Pengolahan Tanah. Skripsi Fakultas Pertanian Universitas Sebelas Maret.

Nasir, M., 2002. Bioteknologi Molekuler Teknik Rekayasa Genetik Tanaman. Citar aditya Bakti, Bandung

Nasution OF., Irmansyah T, Bayu ES. 2017. Pemberian Pupuk Tandan Kosong Kelapa TKKS dan Pupuk Fosfat Pada Pertanaman Sorgum (Sorghum bicolor (L.) Moench) di Gawangan Karet. Jurnal Agroekoteknologi FP USU E-ISSN No. 2337- 6597 Vol.5.No.1, Januari 2017 (7): 47- 54. Program Studi Agroekoteknologi, Fakultas Pertanian.

Poerwanto, R. 2003. Peran Manajemen Budidaya Tanaman Dalam Peningkatan Ketersediaa dan Mutu Buah-buahan. Orasi Ilmiah Guru Besar Tetap Ilmu Hortikultura Fakultas Pertanian, Institut Pertanian Bogor, Bogor.

Rajiman, Yudono, Sulistyaningsih, dan Hanudin. 2008. Pengaruh Pembenah Tanah Terhadap Sifat Fisika Tanah Dan Hasil Bawang 
Merah Pada Lahan Pasir Pantai Bugel Kabupaten Kulon Progo. Agrin Vol. 12, No. 1

Reddy B.V.S and R.P. Sanjana. 2003. Sweet sorghum: characteristics and potential. International Sorghum and Millets Newsletter 44: 26-28.

Rosmarkam, A. dan N.W. Yuwono. 2002. Ilmu Kesuburan Tanah. Kanisius.Yogyakarta.

Sirappa,. 2010. Prospek Pengembangan Sorgum di Indonesia Sebagai Komoditas Alternatif untuk Pangan, Pakan, dan Industri. BPTP Sulawesi Selatan.

Soplanit MCh, Soplanit R. 2012. Pengaruh kandang ela sagu pada berbagai tingkat kematangan dan pupuk Sp-36 terhadap serapan $P$ dan pertumbuhan jagung (Zea mays L.) pada Tanah Ultisol. Agrologia 1(1):60-68

Subeni. 2000. Pengaruh Pengolahan Tanah Terhadap Pertumbuhan dan Hasil Enam Varietas Sorgum Manis. Jurnal Ebryo.

Subiksa, IGM. 2002. Pemanfaatan Mikoriza Untuk Penanggulangan Lahan Kritis. Makalah Falsafah Sains (PPs 702). Edisi April 2002. Program Pasca Sarjana. Institut Pertanian Bogor.

Sulandjari. 2008. Tanaman Obat Rauvolfia serpentina - Ekofisiologi dan Budidaya. UNS Press. Surakarta.
Sumardi M, Kasim, Auzar S, Akhir N. 2007. Respon Padi pada Teknik Budidaya secara Aerobik dan Pemberian Bahan Organik. Jurnal Agrosia 10(1):65-71

Syah MJA., Was I., dan Herizal Y. 2007. Pemanfaatan cendawan mikoriza arbuskula untuk memacu pertumbuhan bibit manggis. Balai Penelitian Tanaman Buah Tropika. $J$ Sinar Tani Ed: 24 - 30 Oktober 2007

Tacoh E, Rumambi A., Kaunang W., 2017. Respons Pertumbuhan Dan Produksi Tiga Varietas Sorgum (Sorghum bicolor (L.) Moench) Dengan Perbedaan Sistem Pengolahan Tanah. Jurnal Zootek Vol. 37 No. 1 : 88-95. Fakultas Peternakan Universitas Sam Ratulangi Manado.

Wariyanto, A., 2002. Bokashi Penggembur Tanah dari Bahan Murah. Harian Umum Suara Merdeka, Senin 8 juli 2002. Universitas Sumatera Utara

Widya Yuwono dan Nasih. 2009. Membangun Kesuburan Tanah Di Lahan Marginal. Jurnal Ilmu Tanah dan Lingkungan. 9(2):137-141

Zulkarnaen, T. Irmansyah, Irsal. 2015. Respons Pertumbuhan dan Produksi Beberapa Varietas Sorgum (Sorghum bicolor (L.) Moench) Pada Berbagai Jarak Tanam di Lahan Kelapa TKKS TBM I. Agroekoteknologi Vol.5,No. 3 